\title{
Ordoliberal Authoritarian Governance in China Since 1978: World Market, Performance Legitimacy and Bio-Sovereign Ordering
}

\author{
Ngai-Ling Sum, Department of Politics, Philosophy and Religion
}

South Atlantic Quarterly 118 (2):381-400, April 2019

DOI: $10.1215 / 00382876-7381206$

\section{From Neoliberalism to Variegated Neoliberalization}

The debate on neoliberalism in China started from the discussion between Harvey and Ong. Harvey, reading neoliberalism as a global class-offensive project promoted by the United States, argued that China is a "strange case" in which a "particular kind of neoliberalism interdigitated with authoritarian centralized control" aimed to restore class power through accumulation by dispossession (2005: 79). Specifically, global capital was exploiting China's huge labour and consumer markets as a new spatial fix for continuous capital accumulation. Ong criticized this structuralist perspective. Adopting a governmentality perspective, she saw neoliberalism as based on mobile technologies for governing "free subjects" that do not conform to a particular political project or bundle of policies. These technologies support complex and strategic governmental interventions that construct new spatial and population categories as parts of neoliberal rationalities $(2006,2007)$.

\section{From neoliberalism to variegated neoliberalization}

This debate can be contrasted with that of variegated neoliberalization (Brenner and Theodore 2002; Brenner, Peck and Theodore 2010). This focuses on hybridized, contradictory and polymorphic processes that are path-dependent, unevenly-layered and geographically conditioned; but also emanate from some global structural changes. This conception has been criticized as serving mainly to provide a useful language to identify and describe processes/dimensions in diverse sites and contexts (d'Albergo 2016: 310). Thus, the approach aims to show how particular concrete cases illustrate, complexify, converge and/or deviate from neoliberalism. Three examples are Peck (2002) on labour markets and Wu (2010) and Lim (2013) on China. While this does not amount to the reductionism of theoretical "subsumption" (Jessop 1982: 71 6 and 212-3), where any specific case is claimed to exemplify general features of neoliberalism, it does privilege neoliberalization as an analytical object and has led other critics to define the approach as akin to a descriptive "natural history" that discovers one or another form of neoliberalism or neoliberalization everywhere (hence nowhere) (Clark 2008: 136-8; Le Galès 2016: 168; Jessop in this issue).

My article addresses these issues by exploring the stepwise movement from abstractsimple concepts to complex-concrete analysis of socioeconomic changes. Here I draw on the logical-historical approach of cultural political economy (CPE), which 
explores how the material and semiotic are articulated not only in general theoretical terms but also in more or less specific contexts (Sum and Jessop 2013: 196-224). It invites concern with three meso-level questions in dealing with the historical variegations in neoliberalism. First, is neoliberalization always the best entry-point for phenomena and processes that, at first sight, could be subsumed under this notion; second, how do discourses, the (il)liberal arts of governing, and their metagovernance, mediate neoliberalization and other processes; and, third, to what extent and how do hybrid forms that emerge from these contingent interactions across different sites and scales lead to new forms of contestation against exploitation and domination?

\section{Mediated variegations and hybridizations}

From a CPE viewpoint, with its interest in socioeconomic imaginaries, the first question broadens the examination of so-called neoliberal imaginaries and their roots in, and ties to, specific historical conjunctures and circumstances. Foucault's The Birth of Biopolitics (2010) highlighted two differentiated veridictions of the market truth posited by neoliberalism: a Chicago-School neoliberal version and a Freiburg ordoliberal one. Chicagoans viewed markets as natural and capable of being extended to all human actions, subjecting them to the permanent audit of its marketized principles (Gane 2012). Foucault drew on Eucken, Röpke and Rustow to characterize German Ordoliberalism. Following Röpke, he identified four major differences from the Chicago School: (1) the renunciation of the naturalness of the market and laissez-faire; (2) an emphasis on competition rather than market exchange; (3) competition as a governmental art to be actively pursued by the state; and (4) the state seeks legitimacy by creating a market-competition order that frames the economy, social, legal and moral arenas (Röpke, 1948: 28). In contrast to Chicagoan hostility to the state, then, ordoliberalism promotes a social market economy in which the state has an important and legitimate role in creating and governing, through contractual, juridico-political, and moral means the market and ensuring market competition (cf. Oksala 2017:198) (see also later).

Regarding the second question, CPE explores how discourses mediate variegation and hybridization. Economic discourses such as economic growth, competitiveness, entrepreneurship, consumption, etc., circulate in policy-consultant circuits across different sites and scales (Sum 2009; Peck and Theodore 2013). In contrast to Ong's conception, CPE sees these mobile discourses and related practices as selectively (re-)contextualized by structurally-embedded actors who seek to remake their institutional-regulatory and everyday life settings (for more on selectivity, see Sum and Jessop 2013: 214-29). Some of these practices can be related to meta-governance or "governance of governance" (Jessop 2011) as they seek to establish coordinating ground rules that steer, guide and collibrate other means of governing.

Third, hybridization refers to the selective rearticulation and recontextualization of discourses that transform meanings and practices. These involve discursive technologies of new ground rules, categories and apparatuses that construct new 
meanings and marginalize others in guiding actions and processes. This is a crucial aspect in analysing the conjuncturally specific, multi-spatial variegation processes of neoliberalization (Sum and Jessop 2013: 220-23)

\section{Making Ordoliberal and Authoritarian Turns in Variegation Research}

To illustrate these points, I look beyond the loci classic of Reaganism and Thatcherism to consider how research on variegation and hybridization can be enhanced by taking account of ordoliberalism and non-western authoritarian settings.

\section{Ordoliberal turn: fear of the masses and socio-political engineering}

Foucault's discussion of German ordoliberalism highlights the art of government in establishing a competition-entrepreneurial order to secure a social market economy. Writing in post-war Germany in the aftermath of military defeat, economic devastation, and loss of sovereignty, Röpke (1948: 243, 246) worried that uprooted masses were losing the "safety of sufficient organic social embeddedness" coming from family, church or local community and this might lead again to over-integration as occurred under Nazism (Biebricher 2011: 178-181). Thus, the ordoliberal imaginary aimed to rebuild the state and ground its legitimacy in a new economic, social and moral order. For Foucault, the ordoliberal art of governing was to establish a "society for the market" and cushion the "society against the market". The former involves ordering the conditions of the market via planning for competition/enterprise; and actively intervening in the society, via legal-contractual means. The latter focuses on what Rustow called Vitalpolitik, i.e., a politics of life. It compensates for the negative effects of the market via social-political engineering of the family and community to produce a set of warm cultural and moral values (e.g., religion). These biopolitical ways of governing (Biebricher 2014: 183-8) encourage the population to become entrepreneurs of the self to improve their living standards and social integration to overcome atomization and massification (Bonefeld 2017a).

\section{Authoritarian turn: interventionism, bio-sovereignty and regulatory statecraft}

For Bonefeld (2017b), ordoliberalism involves 'authoritarian liberalism' - something that can also be observed increasingly in the heartlands of classic neoliberalism. In the China, too, we observe some ordoliberal features such as the focus on state building for national strength/legitimacy, state interventionism to promote entrepreneurship/competitiveness, and a Vitalpolitik based on neo-Confucianism and nationalism. These are hybridized and enmeshed with key authoritarian socialist ground rules/statecraft and selectively (re-)programmed by the Chinese Communist Party since Deng to create new sites of truth claims.

Combining ordoliberal and authoritarian turns also returns us to the issue of sovereign power. Foucault's Discipline and Punish (1975) examined the historical western transition from dynastic monarchies to liberal democratic rule in which the sovereign power of life/death was replaced by disciplinary surveillance and biopolitical power. 
This periodization might suggest that sovereign power is in decline or even disappearing. Yet sovereign, disciplinary and biopolitical power can overlap and coexist and this is especially so in non-western contexts. I now explore this possibility.

In his later work on Security, Territory and Population (2004: 106-7), Foucault proposes that sovereign, disciplinary and biopolitical power can become coimplicated, with their weight varying as conjunctures change. Hindess (1996), among other neo-Foucauldians, echoed this position, arguing that governmentality studies can be extended to study China, especially as the boundary between neoliberal and authoritarian governmental technologies is unclear. Likewise, Dean suggests that an "authoritarian governmentality" comprises an ensemble of biopolitics and sovereignty (1999: 154). These insights stimulated a body of research on non-western governmentalities in colonial, socialist and authoritarian contexts (e.g., Legg 2006; Collier 2011; Bargu 2014). For example, working on Turkey, Bargu (2014: 51-2) examines authoritarian regime through the concept of bio-sovereignty as a contradictory hybridization of sovereignty and biopolitics. On the one hand, sovereign power is permeated and transformed by the rational adoption and incorporation of disciplinary and governmental techniques; and, on the other, disciplinary and governmental techniques are transformed through their fusion with sovereign power. Nonetheless, this mutual interpenetration and cross-fertilization of sovereign tactics and disciplinary and biopolitical governance oriented to controlling and improving the Turkish population cannot guarantee stability and is also contested.

Chinese governmentality has been experimenting with such hybridization in fields such as education, professionals, community, and sexual health (e.g., Anagnost 2004; Sigley 2006; Kipnis 2006; Jeffreys and Sigley 2009). Some studies focus on the neoliberal-biopolitical side of governing the subject at a distance; others insist that the state remains an active participant in China's neoliberal governance (Hoffman 2006). Sigley (2006: 489) concluded that Chinese governmentality involves a "hybrid socialist-neoliberal form of political rationality" based on the co-presence of authoritarian-technocratic techniques and governing of subjects via their own autonomy. This suggests that socialism is not dead but survives in new forms. Inspired by such work, I now introduce the concept of ordoliberal authoritarian governance to explore China's hybridized ordoliberal and socialist authoritarian mode of governing and its contestation.

\section{Ordoliberal Authoritarian Governance in China Since 1978}

Under Deng's leadership, China opened its door to the world market in 1978. The party moved away from its centrally commanding role towards more diffuse but still authoritarian modes of intervention to build a modern nation. Ordo-socialist modes of steering were selectively hybridized with ordoliberal ones to guide public and/or private actors in aiming for growth and social stability. This hybrid form of ordoliberal authoritarian governance has been reinvented several times, notably in response to the Tiananmen movement in 1989 and China's entry to the WTO in 2011. 
This has involved the re-articulation of micropolitical ordo-socialist and ordoliberal techniques across different sites and scales. Relevant measures include: (1) remaking the party's legitimacy and introducing new meta-governance ground rules (e.g., GDPism); (2) re-programming socialist statecraft (e.g., financial control) and administrative guidelines/procedures to exercise panoptic "super-vision" to monitor subordinate units; (3) conducting bio-sovereign ordering of population; and (4) producing ordoliberal art of governing via moral and desires. This hybridization is mediated by the party and other capillary networks (e.g., regional/local governments, think tanks, social communal organizations, schools, media, etc.) to govern the economy, bureaucracy, and society. They supervise, define, open up, and access domains of life (e.g., growth, migrants, population quality, consumption, entrepreneurship, moral, nationalism, etc.) for liberal and illiberal intervention.

\section{Fear of the masses and the making of performance legitimacy}

Deng consolidated power after replacing Mao and his supporters as the central partystate pursued modernization and opened up the economy to the world market. This strategy rested on new economic imaginaries and associated practices. such as 'special economic zones' and concessionary strategies to attract 'foreign direct investment' were pursued. Domestically, Deng's vision in 1979 was to build a "xiaokang society" (moderately and comfortably well-off society) but with "some getting rich first". New economic programmes included lifting price controls and decollectivization of agriculture. These changes led to inflation, economic disparities and rampant corruption. Mass dissatisfaction prompted students, workers and peasants to demanded changes, leading to the Tiananmen movement.

Fearful of the angry masses, Deng, in negotiation with a divided group of party elders, instigated a crackdown and pressed for a post-Tiananmen survival strategy for himself and the party (Pei 2015). Rather than basing legitimacy on Marxist-Leninist ideology, he envisioned a utilitarian turn to deliver growth and stability. The party's new rationale was mediated by new discourses such as "socialist market economy" that regarded "plan" and "market" as mere "economic tools" and "stability maintenance" as "the nonnegotiable task". New ground rules, socialist toolkits and governmental practices were selectively redesigned to manage party legitimacy and rule.

The meta-governance of socialist ground-rule: National GDPism as norm

GDP was selected to showcase party's performance and legitimacy and to guide the metagovernance of economy and society. Before the $12^{\text {th }}$ Party Congress in 1982 , the suggestion was to double real GDP from 710 billion yuan during the 1980s and quadruple it to 2800 billion by 2000 . To this end, the then General Secretary, Hu Yaobang, proposed an "8 percent annual growth rate" as "necessary to maintain social stability and provide jobs for tens of millions of new laborers swarming into the country's crowded job market every year" (China Daily, 2009). This became a mainstay of official rhetoric and "maintaining 8 percent annual growth rate" (bao ba) 
underpinned party's performance legitimacy. Qi (2010: 5) termed this GDPism, which, from Deng (1978-89) onwards, has denoted "the belief that rapid GDP growth should always be the nation's highest priority because it is the panacea for most national issues and the way to consolidate the government's legitimacy".

As an ordo-socialist ground-rule, the political arithmetic of "8 percent growth rate" visibilizes a desirable national policy space that can deliver the twin targets of good growth rate and social stability. Foucault termed this knowledging technique the disciplinary power of normation (2004: 57). In the Chinese case, norms. such as those entailed in GDPism, establish ground rules to: (1) distinguish acceptable and unacceptable policy actions and thus what merits promotion and funding; (2) judge collective and individual performance at different sites and scales; and (3) prescribe desirable and undesirable policy outcomes. Central party-state leaders, sub-national government officials, state-owned enterprise (SOE) executives reiterated this ground rule to showcase their performance and jostle for resources that benefit them and related networks. Faced with deviation from the 8 percent norm, which occurred after the 2008 financial crisis, the Xi leadership developed the "new normal" discourse to negotiate this meta-governance ground rule to a lower target range of 6.5 percent in a decelerating economy.

\section{The socialist statecraft of financial and non-financial control}

This national GDPist ground rule has been hybridized through its combination with pre-existing socialist statecraft of control in non-financial (e.g., appointments, appraisals, dismissals, etc.) as well as financial (e.g., credits, loans, licences, permits, etc.) sites. Financial guidance was accentuated with the appointment of Zhu Rongji to the Politburo Central Committee in 1992. The party extended its control over the financial system by channelling savings to the state-owned sector to stimulate growth. This development statecraft was partly enabled by institutional innovation since 1993, such as establishing the People's Bank of China and other policy banks. These intervene to provide a good investment climate, cheap loans, subsidies and insurance for SOEs (state-owned enterprises), state-linked companies, sub-national governments and their investment arms that could drive GDP growth and capital accumulation. As the economic and political arenas have become intertwined, a group of "princelings" (children of high-ranking party members or officials) who run SOEs/state-linked companies or global business brokerages have been able to convert family ties and political connections into wealth for the families and related networks (Brown 2014).

Apart from financial control/influence, the party also adopts other socialist modes of intervention, including: (1) using the Organization Department and Ministry of Personnel to appoint central SOEs' top leaders; (2) a Cadre Responsibility System that conducts regular appraisals against centrally-determined targets (e.g., 8 percent GDP growth rate); and (3) a Central Commission for Discipline Inspection that 
investigates and punishes malfeasance. The activities of these national control mechanisms, especially the financial ones, were reduced by 2003. Ownership of the national SOEs was transferred to the State Asset Supervision and Administrative Council (SASAC) under the State Council. Its remit is to protect and enhance state asset values based on the statecraft of corporatization (or "administrative recommodification", see Offe 1984). In China, this involves the acceleration of SOE mergers, profit-oriented management techniques, the listing on stock exchanges to enhance capital/market share, SASAC control over the appointments of senior managers (not their top leaders), introducing party cells in business organizations, and so on. This administrative commodification is complemented by the party's use of "atmosphere guidance" (Norris 2016: 52) together with tightening of non-financial means of control, especially during leadership contests conducted in the name of anticorruption.

Bio-sovereign ordering of the population: categorizing and differentiating population via hukou and suzhi

As for the population, most research has focused on the biopolitical side and omit sovereignty issues. Bargu's concept of bio-sovereignty (2014) offers further insights into biopolitics in authoritarian contexts. In China, the technology of hukou (household registration system) as a spatial practice dates back to the feudal era when sovereign control over residence facilitated levies and conscription (Wan 2015: 459). This mode of sovereign control was reinvented in the Maoist era to distribute scarce resources: the population was categorized and differentiated according to birth-place rather than current residency. Population with urban hukou are entitled to state welfare benefits such as housing, education healthcare and retirement benefits. With agricultural decollectivization and the opening to the world market, more young migrant workers moved from rural to urban areas, into township enterprises in the 1980s and industrial enterprises in special zones in the 1990s. However, the urban hukou system excludes them from access to social resources, especially when the system is implemented in large cities.

The hukou way of national-spatial ordering of the population shows that being a rural peasant in China is a biopolitical and social status tied to one's birth rather than an occupation (Zhang 2014). On moving to urban areas, they are classified as "nongmingong" (peasant workers) without hukou and welfare benefits. This illiberal governing technique has been relaxed with the development of non-state enterprises and the demand for low-cost labour since the 1980s. Several local-authority reforms, such as the blue-stamped hukou, allow some more educated and prosperous migrants to gain urban hukou. However, this de facto commodification of residence is still beyond the reach of most migrants, especially in large cities. "Nonmingong" remains a strategic state discourse to confer privileges on the urban elite and assign lower economic value to their migrant bodies as China became a global factory after its WTO entry in 2001. 
Following this momentous move, there was a drive for further reform. The then President Jiang Zeman (1989-2004) promoted the strategy of "Three Represents" in 2002. This called for the party to (1) develop advanced productive forces (e.g., technologies); (2) promote advanced culture (e.g., high ideals, good education and moral integrity); and (3) encourage capitalists to join the party as part of a strategy of co-option. The second goal explicitly linked the quality of the nation with the quality of the individuals. Thus education was an investment in the human body and the national suzhi (human quality) of the population for building productive forces and optimize, if not maximize, value. . Population qualities and their market values are judged by their skills, productivity, entrepreneurship, and mannerism (Anagnost 2004). This biopolitical turn in party rationality involved a technology of the self that makes people self-responsible for raising qualities and optimize themselves as human investment capital through lifelong learning, problem-solving and well-roundedness. The urban middle-classes, especially their children, invest in themselves to raise and valorize suzhi via consumption, lifestyle, education and special coaching classes. Their high suzhi potential is often contrasted with the "uncultured" rural migrant workers with low quality (Wallis 2013: 345), who are in need of management, discipline and training. This biopolitical technology of judgement generates an urban-rural social hierarchy is differentiated by their education, hygienic conditions, lifestyle, material consumption, social etiquette, and so on.

Educational training programmes, which are organized by various state units, NGOs and commercial donors, encourage migrant workers to be more entrepreneurial and self-developmental in learning new vocational/technological skills and relevant social etiquette. Nonetheless, the suzhi-enhancing process occurs in an authoritarian setting where biopolitical governing via "freedom" and "choice" is intertwined/enmeshed with the illiberal hukou arrangements. Bargu's concept of bio-sovereignty can capture some of the complexities of this paradoxical and contradictory juxtaposition of the hukou-suzhi practices. It is neatly illustrated in Wallis's work (2013: 352-3), which shows how some women migrant workers, after attaining suzhi-raising computertraining programmes, were re-subsumed as labouring subjects performing repetitive taylorized processes in digital workshops as China moved from a global factory to a high-tech economy. Thus the competitive logic of global capitalism cancelled the biosovereign push for migrant women to undertake life-enhancing and self-actualizing training and realize their aspiration to join the middle-classes (with urban hukou). Such disappointments are also reflected in the development of the Diaosi subaltern identity (see below).

Governing the society via desires and moral: entrepreneurship, consumption and neoConfucianism

The gaps and cracks continuously created in this paradoxical biosovereign politics are continuously pasted over by creating and intensifying ordoliberal techniques of 
governance through aspirations, desires and moral. For Foucault, ordoliberal policies target two pillars (2010: 241-2). One is to shape "society for the market" in line with the logics of competition and entrepreneurship; the other is to cushion "society against the market" by anchoring individuals in a set of warm cultural and moral values, including nationalism. For example, regarding the first ordoliberal pillar, President Jiang Zemin's 2002 strategy of "Three Represents" aimed to co-opt entrepreneurs, cadre capitalists and educated professionals into the party and help to build the nation. This national official recognition (and even celebration) of entrepreneurs and entrepreneurship encouraged the population to regard education as a way to improve their suzhi and possibly boost their market value. For example, families should plan for their children's education; the unemployed should become micro-entrepreneurs, and students should take responsibility for improving their training/qualifications, including periods of study abroad. New organizations, such as the New Oriental School, provide extra coaching to help students gain high TOEFL scores; and new identities such as "haiquil" (overseas returnees) provide special status and resources for returning scholars. These desires and related efforts and arts of career advancement contribute to the first pillar of building market society (cf. Jacka 2009: 528). These aspirations were encapsulated in Premier Li Keqiang's speech at the World Economic Forum in 2015:

Our people are hard-working and talented. If we could activate every cell in society, the economy of China as a whole will brim with more vigour and gather stronger power for growth. Mass entrepreneurship and innovation, in our eyes, is a "gold mind" that provides constant source of creativity and wealth

These entrepreneurial desires to innovate and excel at the national and individual levels dovetail with the imagined consumption capacities and lifestyle of the entrepreneurial middle classes. Corresponding to the official rhetoric of suzhi, glossy fashion/lifestyle magazines, TV programmes and other media portrayed middleclassness in terms of taste, choice, chic lifestyle, cultural activities and foreign travel (Tomba 2009). Governing desires by dangling consumption carrots before a selfdisciplined population marked the arrival of consumer citizenship in China. One's moral worth as a citizen involves asserting one's rights and choices in the market (Hooper 2005) to enhance their everyday suzhi capital. In turn, expanding consumption supported the party-state's claim to performance legitimacy. Maintaining this consumption-based social contract depends on the continuing ability to save and/or access credit/wealth aided by the party-state. This makes it vulnerable to excess household debt, credit and property bubbles.

These ordoliberal policies to build "society for the market" have further splintering effects, especially when hybridized with hukou as an exclusionary mechanism and the exercise of state financial control to favour large SOEs, state-link companies, princelings and related networks, and other powerful interests. This has prompted mass social unrest in the form of demands for better working/pension conditions, fair 
land-based compensations, anti-corruption, anti-pollution, food safety, etc. In response, the party-state introduced what Foucault termed the second ordoliberal pillar: the cushioning of "society against the market" through a set of warm cultural $/$ moral values. The idea of social harmony has been debated since 2002 and, by 2006, Hu Jintao, the then general secretary, announced the building of a "socialist harmonious society" in the Sixth Plenary Session of the Sixteenth Central Committee meeting. Unlike classical Confucianism, which emphasizes humanity's innate goodness, neo-Confucianism highlights how the cultural and moral values of the national population can be guided and reshaped when faced with rapid social challenges and personal failings. In an explanation issued on 4 March 2006, Hu even listed "Eight Honours, Eight Disgraces" that marked the moral boundary between good and evil (see List 1).

\section{List 1 Harmonious Society and Related Moral Values: "Eight Honours and Eight Disgraces"}

(1) Love the country; do it no harm.

(2) Serve the people; do no disservice.

(3) Follow science; discard ignorance.

(4) Be diligent; not indolent.

(5) Be united, help each other; make no gains at others' expense.

(6) Be honest and trustworthy; do not give up morals for profits.

(7) Be disciplined and law abiding; not chaotic and lawless.

(8) Live plainly, struggle hard; do not wallow in luxuries and pleasures.

Source: See CPC Promotes "Core Value System" to lay Moral Foundation for Social Harmony, XINHUA, Oct. 18, 2006, available at http://news.xinhuanet.com/english/2006-10/18/content 5220576.htm (accessed: 24 April 2018).

These moral values and accompanying normative regulation are emphasized in capacity training of officials, school curriculum, social work, and so on. For example, social work programmes are designed to build social harmony and stability at the communal level of families and neighbours. Communal social work, as a technology of care, employs many techniques to build positive interpersonal relationship and promote a psychology of community care (Yang 2015). It regulates life by getting local people to work and reflect on themselves to build consensus and positive moral values such as filial piety. This strategy has been reinforced under President Xi. His hopebased vision of the "China Dream", nationalism and "new type of great power relations" encourages the release of positive energy and effort to (self-)regulate the population to build a more caring and stable society that surpasses its western counterparts.

The unevenness of ordoliberal authoritarian governance 
This ordoliberal nurturing of moral life and entrepreneurial potentiality co-exist with biosovereign exclusionary politics (e.g., hukou and suzhi), the uneven effects of socialist statecraft, and the disciplinary-exploitative nature of global capitalism. This hybridized ensemble of discursive-material elements under ordoliberal authoritarian governance has contradictory effects. On the one hand, it regularizes and sediments social relations by, for example, co-opting (cadre) capitalists into the party and creating the entrepreneurial middle classes as consumer citizens with suzhi and moral values. On the other hand, its benefits are very uneven and provoke rising resistance from subaltern groups. This is evident in socioeconomic changes in urban settings following the 2008 financial crisis.

The socialist statecraft of financial control aims to provide cheap credit, especially for urban projects that contribute towards China's GDPist project. Following the 2008 financial crisis, China's falling growth rate and rising unemployment stimulated the then Hu-Wen leadership to re-ignite growth with a four trillion Renminbi (RMB) stimulus package (equivalent to 560 billion USD). To facilitate this package, central government encouraged the state-owned banks to lend to national and sub-national governments. To qualify for these loans, (sub-)national governments had to provide matching funding and did so by intensifying land acquisition and leasing land use rights (Wu, Xu and Yeh 2007; Lin 2014). Further funding came from setting up local government financial vehicles to collateralize land-use rights and raise money from state-owned banks and the shadow banking system. Sub-national authorities also allied with private developers and auxiliary building industries. These measures fuelled debt-based megaprojects and other real estate ventures, increased extra-budgetary government income, and boosted individual careers (Sum 2017). Along with a commercial housing boom, this inflated property bubbles in major cities and led to rising residential rents (Qing and Wang 2014).

\section{New Subalternity in Ordoliberal Authoritarian Governance: Making of Diaosi Identity}

Migrant workers without urban hukou endure the disciplinary-exploitative capitalist conditions in China's global factory and digital workshop. Long working hours, low pay and lack of welfare benefits are common in factories such as Foxconn (Bieler and Lee, 2017). This has provoked increasing labour resistance from state trade union of AllChina Federation of Trade Unions or informal labour NGOs. This collective classbased labour consciousness intersects with the rise of other grassroot-subaltern identities, especially among second- or third-generation migrant workers. Their agency and subjectivity occupy contradictory locations of subsisting in marginal and subaltern conditions but also aspire to gain urban hukou and embrace suzhi lifestyle.

Industrial and service migrants must also endure rising house prices or rent. They often rely on employer-provided dormitories (Pun 2005), rent sub-standard accommodation at the peripheries of towns or reside in liminal spaces (e.g., balconies, 
roof tops or underground accommodation) in central urban conurbations of global cities. In Beijing, some migrants rented/shared small rooms at around US\$ 65 per month in 2014 in underground air raid shelters/storage spaces with communal toilets/kitchens and no natural light. About a million low-wage service workers (e.g., waiters, hairdressers, janitors, shop assistants, street peddlers, chefs, security guards, construction workers, etc.) occupy this subterranean housing in 2014 (Pulitzer Centre 2015). These subaltern groups are dubbed a "rat tribe" and Sim (2015) has portrayed their lives photographically. I now explore the making of Diaosi identity as a mode of resistance that expresses the contradictory location of urban migrant workers.

\section{The self-representation of Diaosi subjectivity}

Since late 2011, many young migrant workers, who are users and makers of Internet pop culture and social media, feel left behind. They increasingly self-narrate their marginality and subalternity affectively by self-identifying as "Diaosi". The "Diaosi" subject position - literally, fans of a celebrity footballer here - emerged in on-line battles between rival fans. They then transposed the meaning from celebrity worship to "fans of penis", which is a close homonym (Sum 2017). This transposition soon went viral on social media. Within two months after its coining in 2011, it generated 41.1 million search results and 2.2 million blog posts on Google and China's Twitter-like Weibo respectively (Lui, 2015). Young subalterns started to proclaim themselves as "Diaosi" and all kinds of chat rooms and social media were set up in response (e.g., $Y Y$ and $Q Q$ chats).

New biopolitical meanings were added as the discourse and identity circulated in the social media. The new identity soon expressed marginality, exclusion, devaluation, frustration, hardship, and social pain as well as unfulfilled consumer and romantic desires of migrant workers. They represent themselves as coming from underprivileged background earning a meagre wage, consuming little and having no social connections. ${ }^{1}$ Their meagre income/consumption/borrowing capacity and low social standing are coupled in social-emotional terms with a sense of living a devalued life of long working hours, poor housing, uncertain career, living away from family, guilt towards parents at home, and empty emotional life with little love/romance/intimacy. This emptiness and loneliness are often highlighted in Diaosi narrations of how they spent Valentine's Day, Christmas, festive seasons and the small hours of the night looking for Internet companions. Such affective discourses from the margins express collective social experiences grounded in the exclusionary practices of hukou and suzhi as well as inequalities generated in the everyday economic and social life of global capitalism.

\section{Resistance via imagined biopolitical binary}

This everyday making of Diaosi subalternity is expressed further through a biopolitical binary that depicts two main gendered body types based on their unequal access to 
power networks, consumption, love, romance and intimacy. First, male Diaosi selfdeprecate as "poor, short and ugly" losers (Marquis and Yang 2013: 3). With meagre income and unattractive physiques, they construct themselves as unable to impress girls by showering them with material gifts and/or charm. They have 'no house, no car and no bride/girlfriend' and spend most of their time at home, use cheap mobile phones, surf on the Internet, and play media games such as DotA. This male-oriented diaosi construction has gradually spread to female subalterns (Sum 2017).

Second, the Diaosi identity expresses social inequalities by juxtaposing its own body with an elite type, Gaofushuai, who are (1) "tall, rich and handsome"; and (2) "princelings" with special social connections enabling them to gain socialist (non)financial advantages. Diaosi regard this second group as "superior": they enjoy the 'three treasures' (iPhone, sports car and designer watch) (Marquis and Yang 2013: 9) and can attract beautiful girls. This binary contrast involves a mix of latent critique, self-mockery, self-protection, and self-entertainment (Yang, Tang and Wang, 2015). It is a mundane way of protesting and relieving pressure in an authoritarian system that combines the drive for GDP growth/consumption with an exclusionary statecraft tied to a biopolitical mode of governing. The resultant gaps between these two imagined groups are further highlighted online via satirical cartoons, everyday photographs, TV shows, fantasy talks, etc. These include comparing their diverse modes of transport (bus vs. BMW), brands of smartphones (Nokia vs. iPhone); eating places (side-street stores vs. expensive restaurants), and romantic encounters.

Diaosi also construct themselves as "romantically unlucky" as their ideal girlfriends (named "goddesses") are "Bafumei" (fair-skinned, rich and pretty) and not "Heimu'er" ("Black Fungus" women who are overly experienced sexually). Given their meagre income, unattractive physique and the existence of a match-making industry catering mainly for rich men (Larmer 2013), Diasoi expect to lose out in the competition for Bafumei girls by rich and powerful Gaofushuai/princelings. These Diaosi narrations reflect a mix of precarious life with little money and no background; the self-mockery of a fate with no future/hope; the emotional emptiness of being shunned/mocked by "goddesses", the latent hostility towards social elitism embodied by Gaofushuai/ princelings; and the despair of not being accepted. Yet these self-deprecating views also implicitly endorse the dominant norms, sexual stereotypes, and unfulfilled ordoliberal dream in entrepreneurial and consumer society.

Some subalterns reject this marginality, others accept it. Some indulge in consumption and/or seek pleasure from the culture industries (e.g., live-streaming on social media). Others live in hope and assume personal responsibility to fulfil these entrepreneurialconsumerist dreams by improving "suzhi", obtaining better qualifications, finding good jobs, meeting good marriage partners, and moving from their underground existence and gaining hukou. This system is by no means consistent or coherent; it contains "contradictory consciousness" and fragmentation as subalterns seek to come to terms 
with China's emerging ordoliberal authoritarian governance and its officially promoted, but unevenly developing, consumer citizenship regime.

\section{Re-establishing control under Xi's leadership}

This embodiment of marginal identity online coexists with other ideational clusters on the social media. They range from pro-Mao to pro-market/American as well as nationalist, religious and social equality groups (Shi-Kupfer et al. 2017). Together with more materially-based challenges such as labour and pension strikes, these groups are seen to threaten China's social stability. The Xi leadership is responding by tightening control via: (1) intensifying censorship, firewall and key-word blocking; (2) promoting his personality cult; (3) placing party cells in private and foreign businesses; and (4) creating an online "social credit" system. This latter system is a 2014 government initiative to create a big-database on the financial creditworthiness and social behaviour of citizens, companies and NGOs. When fully implemented in 2020 , this way of quantifying "virtue" and awarding people with high "social credit" scores is a further development for the digital age of socialist statecraft of keeping personal records from cradle to grave. As a bio-sovereign-disciplinary technique, it (1) encourages citizens to self-responsibilize to become trusted citizens in building national morality; and (2) enhances the party's discipline-surveillance-security mechanisms in monitoring and controlling the masses with the use of big data technologies. This kind of digital bio-sovereign and disciplinary technique aims to provide a techno-moral fix that helps to sustain party rule but also adds to the underlying unevenness and struggles of everyday life for the subaltern groups to accumulate not only suzhi but also related moral scores.

\section{Concluding Remarks}

This article employs CPE to pose three meso-level questions that can facilitate movement from general concepts and propositions about the hybridized, variegated nature of neoliberalization to specific empirical cases. First, is neoliberalization always the best entry-point for phenomena and processes that, at first sight, could be subsumed under this notion; second, how do discourses, the (il)liberal arts of governing, and their metagovernance, mediate neoliberalization processes; and, third, to what extent and how do hybrid forms that emerge from these contingent interactions across different sites and scales lead to new forms of contestation against exploitation and domination? In answering these questions, inspired by Foucault, I adopt an ordoliberal entry-point and combine it with a greater emphasis on the authoritarian nature of neoliebralizations. Together, I suggest that these turns provide a productive perspective on variegation research, especially in non-western settings.

I introduced the concept of ordoliberal authoritarian governance and illustrated from the case of (post-)Deng China. To maintain the party-state's performance legitimacy, new meta-governance ground rules have been developed that hybridize socialist 
statecraft, bio-sovereign and ordoliberal techniques to govern desires and morals. This ensemble of discursive-material elements become regularized and sedimented in an authoritarian mode of ordoliberal-socialist rule. But this generates unevenness and contradictions as China deepens its national authoritarian rule and its ties with global capitalism. One contradictory response in these changing social relations is the emergence of a subaltern Diaosi identity that uses corporeal categories, humour and social pain to subvert and submit to China's ordoliberal authoritarian mode of rule in the development of the world market.

\section{Endnote}

${ }^{1}$ The Market and Media Research Centre, Beijing University, conducted a survey on the 2014 Living Conditions of Diaosi. Of 210,000 youths interviewed, over $60 \%$ described themselves as Diaosi. They earned RMB 2917.7 (USD 479). From this, they spent RMB 500 (USD 81) on rent, RMB 39 (USD 6) per day for 3 meals, RMB 1076 (USD 174) to send to parents, and RMB 500 (USD 81) on vacations.

\section{References}

d'Albergo, Ernesto. 2016. "What is the Use of Neoliberalism and Neoliberalization?"

The Open Journal of Sociopolitical Studies 9, no. 2: 308-38. sibaese.unisalento.it/index.php/paco/article/download/16307/14058.

Anagnost, Ann. 2004. "The Corporeal Politics of Quality." Public Culture, no. 16: 189208.

Bargu, Banu. 2014. Starve and Immolate. New York: Columbia University Press.

Biebricher, Thomas. 2011. "The Biopolitics of Ordoliberalism." Foucault Studies, no. 12: $171-91$.

Bieler, Andrea, and Lee Chun-Yi, eds. 2017. Chinese Labour in the Global Economy. London: Routledge.

Bonefeld, Werner. 2017a. Strong State and the Free Economy. New York: Rowman \& Littlefield.

Bonefeld, Werner. 2017b. "Authoritarian Liberalism: From Schmitt via Ordoliberalism to the Euro." Critical Sociology, 43, nos. 4-5: 747-61.

Brenner, Neil, Peck Jamie and Theodore Nick. 2002. "Cities and the Geographies of 'Actually Existing Neoliberalism'." Antipode 34, no. 3: 349-79. 
Brenner, Neil, Peck Jamie and Theodore Nick. 2010. "Variegated Neoliberalization:

Geographies, Modalities, Pathways." Global Networks, 10, no. 2: 182-222.

Brown, Kerry. 2014. The New Emperors. London: I.B. Tauris.

China Daily. 2009. "Eight Percent Protection." 11 March.

http://language.chinadaily.com.cn/2009npc/2009-03/11/content_7566944.htm.

Clark, John. 2008. "Living With/In and Without Neoliberalism." Focaal, no. 51: 135-47.

Collier, John. 2011. Post-Soviet Social. Princeton, NJ: Princeton University Press.

Dean, Mitchell. 1999. Governmentality. London: SAGE.

Foucault, Michel. 1991. Discipline and Punish. Harmondsworth: Penguin.

Foucault, Michel. 2004. Security, Territory and Population. Basingstoke: Palgrave.

Foucault, Michel. 2010. The Birth of Biopolitics. Basingstoke: Palgrave.

Gane, Mike. 2008. "Foucault on Governmentality and Liberalism." Theory, Culture and Society, 25, no. 7-8: 353-63.

Harvey, David. 2005. A Brief History of Neoliberalism. Oxford: Oxford University Press, Hindess, Barry. 1996. Discourses of Power. Oxford: Blackwell.

Hoffman, Lisa. 2006. "Autonomous Choices and Patriotic Professionalism.” Economy \& Society, 35, no. 4: 550-70.

Hooper, Beverley. 2005. The Consumer Citizen in Contemporary China. Available at http://www.niaslinc.dk/gateway to asia/nordic webpublications/x506003816.pdf (accessed April 11, 2018).

Jacka, Tamara. 2009. "Cultivating Citizens: Suzhi Discourse in the PRC." Positions,13, no. $7: 523-35$

Jeffreys, Elaine and Gary Sigley. 2009. Chinese Governmentalities. London: Routledge.

Jessop, Bob. 1982. The Capitalist State: Marxist Theories and Methods. Oxford: Martin Robertson.

Jessop, Bob. 2011. "Metagovernance." In SAGE Handbook of Governance, edited by Mark Bevir, 106-23. London: SAGE.

Kipnis, Andrew. 2006. "Suzhi: a Keyword Approach." The China Quarterly, no. 186: 295-313.

Larmer, Brook. 2013. "The Price of Marriage in China." The New York Times, 9 March, http://www.nytimes.com/2013/03/10/business/in-a-changing-china-newmatchmaking-markets.html? $\quad r=0$. 
Le Galès, Patrick. 2016. "Neoliberalism and Urban Change: Stretching an Idea Too Far." Territory, Politics and Governance, 4, no. 2: 154-72.

Legg, Stephen. 2006. "Governmentality, Congestion and Calculation of Colonial

Delhi." Social and Cultural Geography, 7, no. 5: 709-29.

Lim, Kean Fan. 2014. "Socialism with Chinese Characteristics: Uneven

Development, Variegated Neoliberalization and the Dialectical Differentiation of State Spatiality." Progress in Human Geography, 38, no. 2: 221-47.

Lin, George. 2014. "China's Landed Urbanization." Environment and Planning A, 46, no. 8: 1814-35.

Lui, Jaycee. 2015. China's Disaffected Diaosi Tribe. Available at http://gbtimes.com/life/chinas-disaffected-diaosi-tribe (accessed January 14, 2018).

Marquis, Chris and Yang Zoe. 2013. Diaosi: Evolution of a Chinese Meme, Available at http://www.civilchina.org/2013/07/diaosi-evolution-of-a-chinese-meme/ (accessed February 14, 2018).

Norris, William. 2016. Chinese Economic Statecraft, Commercial Actors and Grand Strategy. Ithaca, NY: Cornell University Press.

Offe, Claus. 1984. Contradictions of the Welfare State. London: Hutchison.

Oksala, Johanna, 2017. "Ordoliberalism as Governmentality." In The Birth of Austerity, edited by Thomas Biebricher and Frieder Vogelmann, New York: Rowman \& Littlefield,

Ong, Aihwa. 2006. Neoliberalism as Exception. Durham, NC: Duke University Press.

Ong, Aihwa. 2007. "Neoliberalism as Mobile Technology." Transactions of the Institute for British Geographers, 32, no. 1: 3-8.

Peck, Jamie, 2002. "Labor, Zapped.Growth, Restored? Three Moments of Neoliberal Restructuring in the American Labor Market." Journal of Economic Geography, 2, no. 2: $179-220$.

Peck, Jamie and Nick Theodore. 2015. Fast Policy. Minneapolis: University of Minnesota Press.

Pei, Minxin. 2015. "The Twilight of the Communist Party in China." American Interest, 11, no. 4, https://www.the-american-interest.com/2015/11/12/the-twilight-ofcommunist-party-rule-in-china/.

Pun, Ngai. 2005. Made in China, Durham: Duke University Press. 
Pulitzer Centre. 2015. Beijing's Rate Tribe. Pulitzer Centre of Crisis Reporting.

Available at http://pulitzercenter.org/project/asia-china-beijing-rat-tribe-migrantworkers-poverty-service-poor-housing (accessed January 14, 2018).

Qi, Dongtao. 2010. “GDPism' and People's Livelihood in China.” EAl Bulletin, 12, no. 1, 5 May.

Qing, Koh Gui and Aileen Wang. 2014. "Rents in China Are So High that Some

People are Moving Underground." Business Insider, 5 Jan,

http://www.businessinsider.com/rents-in-china-are-getting-so-high-that-somepeople-are-moving-underground-2014-1? IR=T

Röpke, Wilhelm. 1948. Civitas Humana: A Humane Order of Society. London: William Hodge.

Shi-Kupfer, Kristin, Marike Ohlberg. Simon Lang and Bertram Lang. 2017. "Ideas and Ideologies Competing for China's Political Future." Available at https://www.merics.org/sites/default/files/2018-

1/171004 MPOC 05 Ideologies 0.pdf (accessed 16 January 2018).

Sigley, Gary. 2006. "Chinese Governmentalities." Economy \& Society, 35, no. 4: 487508.

Sim, Chi Yin. 2015. "Meet the Million Migrant Workers Living Beneath Beijing's

Streets." Creativetimereports, 24 Jan,

http://creativetimereports.org/2015/01/24/sim-chi-yin-rat-tribe-beijing-

underground-apartments/.

Sum, Ngai-Ling. 2009. "The Production of Hegemonic Policy Discourses." Competition and Change, 9, no. 4: 546-73.

Sum, Ngai-Ling. 2017. "The Making of the Subaltern Subjects: Embodiment, Contradictory Consciousness and Re-hegemonization of the Diaosi in China." Globalizations, 14, no. 2: 298-312.

Sum, Ngai-Ling and Bob Jessop. 2013. Towards a Cultural Political Economy. Cheltenham: Edward Elgar.

Tomba, Luigi. 2009. "Of Quality, Harmony, and Community: Civilization and the Middle Class in Urban China." Positions, 17, no. 3: 591-616.

Wallis, Cara. 2013. "Technology And/As Governmentality." Communication and Critical/Cultural Studies, 10, no. 4: 341-58.

Wu, Fulong. 2010. "How Neoliberal is China's Reform?" Eurasian Geography and Economics, 51, no. 5: 619-31. 
Wu, Fulong, Xu Jiang and Anthony Yeh. 2007. Urban Development in Post-Reform China: State, Market and Space. London: Routledge.

Yang, Jie. 2015. Unknotting the Heart. Ithaca, NY: Cornell University Press. 